TO BE HUMAN IS TO BE FREE:

\title{
A PROTESTANT CONTRIBUTION TO THE DISCOURSE ON HUMAN DIGNITY
}

\author{
Willem Fourie \\ Research Associate \\ Nelson Mandela Metropolitan University
}

\begin{abstract}
In this article Wolfgang Huber's work on freedom is used to reflect on human dignity from a Protestant perspective. It is argued that the close connection between freedom and human dignity in Huber's work allows for a meaningful construction and that it can contribute to the discourse on human dignity in the context of South Africa's secularity and (religious) pluralism.
\end{abstract}

Key Words: Human Dignity, Freedom, Responsibility, Democracy, Wolfgang Huber

\section{Introduction}

Freedom is a key concept ... in the biblical witness. According to this witness, freedom is God's great gift to humankind... To protect the entrusted gift of freedom and to use the liberation from sin responsibly are God's purposes for humankind (Huber, 2007b). ${ }^{1}$

Freedom is a central theme in the work of the German theologian and social ethicist Wolfgang Huber. His work on 'communicative freedom' can be read as his reflection not simply on a comprehensive understanding of freedom, but on the human condition as such. In most cases it is possible to view 'freedom' and 'human dignity' as interchangeable concepts. In terms of Huber's work, it is possible to argue that to be human means to be free, and not in a limited sense, but indeed freedom understood in a comprehensive manner.

In this article, his work on freedom - as expressed in his concept 'communicative freedom' - will form the basis for distilling some thoughts on human dignity. It should be added that this argument is meant as a construction in an interpretative sense. Before examining three statements on being human, some cursory remarks need to be made on the relation between freedom and human dignity in Huber's work, and on his concept of communicative freedom.

\section{Freedom and Human Dignity}

Huber places his understanding of freedom as continuing from the Reformation's radical rediscovery of freedom. He traces the development of modern human rights through the Reformation in order to illustrate the close relationship between Christian freedom and human dignity.

\footnotetext{
"Freiheit ist ein Schlüsselbegriff ... des biblischen Zeugnisses. Diesem Zeugnis gemäß ist Freiheit die große Gabe Gottes an den Menschen. ... Die ihm als Geschenk anvertraute Freiheit zu bewahren, die in der Befreiung aus der Sünde erneuerte Freiheit verantwortlich zu gebrauchen, ist Gottes Auftrag an den Menschen."
} 
The Italian humanists took up the biblical theme of humanity as created in the image of God already in the $15^{\text {th }}$ century, with philosophers like Count Giovanni Pico della Mirandola (1463-1494) describing humanity as corresponding to God, with unending opportunities on which to act (Huber, 1996b:228). The Spanish late-scholasticism of the first half of the 16th century also played an important role in emphasising the equal dignity of all people (Huber, 1996b:229). This was especially due to the widening of the horizons of Spanish thought, and was largely brought about by the explorations of the 15 th century.

However, Huber (1996b:228-231) understands the Reformation to have radicalised these movements by means of its renewed emphasis on shared and equal freedom, i.e. the dignity of all persons. In Rechtfertigung und Recht (2001c:18-33), Huber sketches Martin Luther's dramatic rediscovery of this conviction. Luther's basic question concerned the meaning of 'God's righteousness', , and specifically how a sinful person can be accepted by a righteous God (Huber, 2001c:23, Jüngel, 1999). Rather than understanding God's righteousness as only 'active' righteousness, in other words enforcing his righteousness by means of his power to punish, Luther rediscovered the 'passive' dimension of God's righteousness, or God's gracious justification of the sinner (Huber, 2001c:23-24). Luther's discovery of the second part of Romans 1:17, namely that God's righteousness 'is revealed through faith for faith' (NRSV) forced him to revise his understanding of God and God's relationship with humanity. God's righteousness is therefore given to the sinner and cannot be achieved (Huber, 1993a:24).

The confessional wars that followed the Reformation led to a new development. It became clear that religious convictions - especially when used to partly legitimate legal systems - can lead to violence, which led theorists such as Grotius and Hobbes to argue for a legal system that was not based on a belief in God's existence and its ability to shape religious confessions. The era of legal positivism was inaugurated by the consequent conviction that the state itself should be the source of the legal system. As the power of the state increased, the need for counterbalances was increasingly articulated. Basic and civil rights were seen as the most important of these counterbalances, and they were programmatically formulated during the French and American Revolutions (Huber, 1996b:139, 2001c:15).

The Enlightenment provided the foundational ideas for further developments. The 'discovery' of human subjectivity and autonomy by the philosophers of the Enlightenment, led - despite some of its questionable consequences - to the legal acceptance of the person as an autonomous legal subject. ${ }^{3}$ This stage can be seen to have come to a conclusion in modern societies with the United Nations' Universal Declaration of Human Rights that was accepted in 1948 (Huber, 1996b:139, 2001c:15-16).

These cursory remarks on Huber's view of the relation and societal influence of the Protestant understanding of the relation between freedom and human dignity will serve as basis for the rest of the discussion. However, before moving to the three statements on being human, some last introductory remarks need to be made on Huber's concept of 'communicative freedom'.

\footnotetext{
2 "For I am not ashamed of the gospel; it is the power of God for salvation to everyone who has faith, to the Jew first and also to the Greek. For in it the righteousness of God is revealed through faith for faith; as it is written, "The one who is righteous will live by faith"” (Romans 1:16-17, NRSV).

3 For the reception of human rights in societies influenced by other religious and cultural ideas than those that were responsible the concept of human rights Huber makes use of, cf. Bloom, Martin \& Proudfoot, 1996.
} 


\section{Communicative Freedom}

Huber makes use of the term 'communicative freedom' to denote the comprehensive and critical nature of the rediscovery of freedom by the Reformation. This concept allows for the critical potential of Christian freedom to be unlocked and specifically aims both at liberating the Christian discourse on freedom from the private sphere of human existence and bridging the gap between individualised and overly communitarian understandings of freedom.

Huber originally encountered the term in the work of the philosopher Michael Theunissen, his friend and fellow member of the Social Democratic Party of Germany. ${ }^{4}$ Theunissen originally made use of communicative freedom in the context of Hegel's philosophy in his book Sein und Schein: Die historische Funktion der Hegelschen Logik (Frankfurt a. M 1978). ${ }^{5}$ Although Theunissen also emphasises the role of 'the other' in the understanding of freedom, Huber makes little use of the original context of the term.

When formulating the connection between individuality and sociality within current-day socio-historical realities, communicative freedom sets in motion dialogue with two significant traditions of interpreting freedom. When Huber emphasises the close connection between human sociality and human individuality (programmatically in 1985:117-119, 1990b:57-65, 1993a:71, 1996a:106) he is applying the Reformational understanding of freedom in order to bridge the distance between so-called 'negative freedom' and 'positive freedom'. Isaiah Berlin referred to these in his famous inaugural lecture at the University of Oxford, and which was published as 'Two Concepts of Liberty' (Berlin, 1958, 2006).

The concept of negative freedom is grounded in the liberal intellectual tradition, according to which freedom is understood as the freedom of the individual from interference by others (Huber, 1996b:222). Concepts such as individuality, responsibility, rationality, dialogue and rights are of importance in this tradition. Exponents of positive freedom emphasise that individual freedom is always dependent on presuppositions that should be formulated and maintained in broader contexts (cf. e.g. the explanation in Huber, 1996b:222). Concepts such as sociality, justice, solidarity and equality are of importance in this tradition.

Huber's comprehensive understanding of freedom, based on the close connection between freedom and human dignity, forms the basis for our discussion in this article. It will be used to construct and elucidate three statements on being human, namely, to be liberated, answerable and in relationship.

\section{Three Statements on Human Dignity from a Protestant Perspective}

\section{To be Human is to be Liberated}

God values every person in a special way. Precisely in this way does God bestow every person with dignity that is stronger than differences brought about by achievement or

4 Cf. e.g. Huber's dedication of Folgen christlicher Freiheit: Ethik und Theorie der Kirche im Horizont der Barmer Theologischen Erklärung to Theunissen (and Alfred Schindler) (1985:9).

5 Schuhmacher describes Theunissen's use of the concept as follows: "Dieser Begriff meint eine Öffnung des sich selbst loslassenden Ich auf den anderen hin und das Konstituiertwerden des Selbst vom anderen her" (2006:255) 
ability. ... [T] he equal dignity of all persons [is] grounded in God's unsearchable goodness (Huber 2008:107). ${ }^{6}$

Fundamental to the Protestant understanding of being human is the experience of being liberated. Human existence is constituted by God's liberation, which gives human dignity fundamentally - an inalienable character (Huber, 1985:211). Huber makes use of Christian salvation history to describe this inalienable freedom. He understands God's act of creation as the constitutive moment of freedom (1999:171), as God liberates humanity from nonexistence into existence. God also renews the bestowed freedom by means of his salvific initiative. Human directionlessness, ${ }^{7}$ or relationlessness, ${ }^{8}$ causes freedom to be endangered, but Christ's life, death and resurrection serve as the paradigmatic re-establishment of the inalienable character of freedom and the liberation from the ultimate power of sin (Huber, 1999:72; 1996b:107).

By using terminology developed by Eberhard Jüngel ${ }^{9}$ Huber calls Christ the Truth that has power over life and death. ${ }^{10}$ The truth Christ incarnates is experienced as a liberating power for it liberates humanity from the 'basic lie of human existence': ${ }^{11}$ the conviction that humanity is able to produce life and meaning on its own. Christ therefore renews the gift of freedom that was already constituted at the advent of creation by reaffirming the basic truth of human existence, namely that human freedom is inalienable. To be human is, in its basic sense, to be liberated.

Huber (2008:232ff) places God's liberation in perspective by connecting the salvation brought by Christ to its ultimate consummation (cf. also Huber, 1999:175). With Christ's incarnation as the liberating Truth the coming of God's kingdom already commenced, as Christ's resurrection confirmed (Huber, 2008:222). Therefore, even seemingly contradictory experiences do not contradict or disable hope. In Christ, God's willingness to suffer with his creation (Leidensempfindlichkeit) is shown to be the connection between 'God's eternity', in other words his coming kingdom, and the current imperfection of reality (Huber, 2008:225). God's eternity liberates humanity from the ultimate power of the imperfection of current realities.

In contrast to understanding human worth as a substance that is owned by the individual, the Christian witness - especially since the Reformation - understands human dignity to be grounded in the relationship God initiates with humanity. Through God's

6 "Er würdigt jeden auf besondere Weise. Gerade darin verleiht er allen Menschen eine Würde, die stärker ist als die Unterschiede der Leistung oder des Vermögens. ... [D]ie Begründung der gleichen Würde jedes Menschen [ist] in der unausforschlichen Güte Gottes."

7 Huber uses this term from Hegel's work to denote sin.

$8 \quad$ In Der christliche Glaube Huber (2008a:69-73) partly revises his description of sin. Whereas he uses Hegel's term Orientierungslosigkeit in many of his earlier descriptions of sin, notably also in Kirche in der

Zeitenwende (1999), he does not use it in Der christliche Glaube. Instead he describes sin as in the first instance being separated from God (2008a:69). He then explicates this separation as the negation of the three theological virtues of faith, hope and love by Unversöhntheit, Hoffnungslosigkeit and Lieblosigkeit.

Separation from God therefore implies also the separation from fellow humans and sin ultimately leads to Beziehungslosigkeit (2008a:71).

9 Huber uses a set of arguments developed by Eberhard Jüngel in a speech delivered in 1992. For this argument, cf. also "Theologie und Kirchenleitung - Vortrag zu Ehren von Eberhard Jüngel, Tübingen" (2005b),

"Nachfolge" (2006a); "Barmherzigkeit mit den Zweiflern - Überlegungen zum Weg unserer Kirche" (2006f),

"Kirche im Aufbruch - Eine Zeitansage zum Kongressthema der Arbeitsgemeinschaft Missionarische Dienste in Leipzig" (2006c) and "Gemeinschaft gestalten - Evangeliches Profil in Europa" (2006d).

10 Cf. also John 8:32 where Christ is identified as the Truth that liberates his people.

11 Huber uses the word Lebenslüge. Cf. e.g. "Nachfolge heute" (2006a) "Kirche im Aufbruch" (2006c) and "Gemeinschaft gestalten - Evangelisches Profil in Europa" (2006d). 
justification ${ }^{12}$ one discovers oneself as a being that cannot be defined in terms of any of one's abilities or mistakes, but as a being that transcends any attempt at a final definition (Huber, 1993a:155). ${ }^{13}$

That I am a person is not dependent on my deeds or - thank God - on my misdeeds. I can act responsibly because I am respected (by God) beyond my responsible actions. This is the most fundamental meaning of 'justification' (Huber, 2001b). ${ }^{14}$

Therefore, God's constitution of human dignity implies that relationality is a constitutive element for a Christian understanding of human dignity (Huber, 2006b):

Nowhere is humanity given a higher standing than in the Judeo-Christian tradition where the person is understood as God's counterpart. It understands humanity's dignity not as a substance that 'belongs' to the individual, but as constituted by the relationships by means of which life is lived. Among these relationships, however, God's relationship with humanity is the most important. The relationship with the people with whom life is shared, the world within which life is lived and to oneself is of resultant importance. ... This is expressed in the idea of 'image of God'. ${ }^{15}$

Huber makes use of Kantian terminology to express the inalienable and personal character of human dignity. The most important Kantian idea Huber takes up in his work is that the person being is an 'end in itself' and not a 'means to an end' ${ }^{16}$ A human being is therefore always a 'person' and never simply an 'object' (Sache). In some instances, Huber (e.g. 2004a) expresses this distinction as a distinction between 'worth' (Wert) and 'dignity' (Würde). Huber (1990a:222-223) cites Kant to substantiate this distinction:

In the 'kingdom of ends' everything has either a price, or dignity. Something with a price can be exchanged for something else, for an equivalent. However, that which does not have a price or equivalent has dignity. ${ }^{17}$

12 Huber makes relatively little use of the concept of sanctification. Huber (1993a:156) is indeed of the opinion that the Calvinist emphasis on the connection between God's gracious election and sanctification is of importance and regards it as an important development of Luther's initial discovery, but rarely develops it further. Here he picks up the Calvinist connection between individual freedom and responsibility. Cf. in this regard Sovereign grace: The place and significance of Christian freedom in John Calvin's political thought by William Stevenson where he describes "irreducible, yet partial" individual freedom (1999:11-57) as the Calvinist basis for "corporate action, but under judgement" (1999:59-103).

13 It should be noted, however, that in Der christliche Glaube (2008:38-49) Huber chooses to motivate human dignity not by means of God's gracious justification, but by means of his act of creation. However, this apparent shift of focus does not change the central elements of his understanding of human dignity. In Die christliche Glaube (2008:38) Huber's main categories of describing human dignity are the person described as an "answering being", relationships as the realisation of personhood and the importance of personal responsibility, all of which correspond to the central aspects of human dignity in the rest of his work.

14 "Daß ich Person bin, ist nicht abhängig von meinen Taten und deshalb Gott sei Dank auch nicht von meinen Untaten. Ich kann verantwortlich handeln, weil ich geachtet bin über all mein verantwortliches Handeln hinaus. Das ist der ganz elementare Sinn dessen, was wir mit dem Wort 'Rechtfertigung' beschreiben."

15 "Nirgendwo wird höher vom Menschen geredet als in der jüdischen und christlichen Tradition, die im Menschen ein Ebenbild, ein Entsprechungsbild Gottes sieht. ... Unter diesen Beziehungen aber steht die Gottesbeziehung des Menschen oben an. Die Beziehung zu den Mitmenschen, mit denen er sein Leben teilt, zu der Lebenswelt, in der er sich bewegt, und zu sich selbst treten dem zur Seite. Der Mensch, der sich in solchen Beziehungen vorfindet und der diese Beziehungen ausdrücklich thematisieren kann, ist Person; das kommt im Begriff der Gottebenbildlichkeit zum Ausdruck."

16 This Huber does, in e.g. "Flugblätter der Freiheit. Verantwortliches Handeln aus christlichen Wurzeln" (2006b) and "Dass der Mensch mehr ist als seine Taten. Das christliche Menschenbild im Licht der Rechtfertigungsbotschaft" (2007a).

17 "Im Reiche der Zwecke hat alles entweder einen Preis, oder eine Würde. Was einen Preis hat, an dessen Stelle kann auch etwas anderes, als Äquivalent, gesetzt werden: was dagegen über allen Preis erhaben ist, mithin kein Äquivalent verstattet, das hat eine Würde." 
This understanding of human existence coincides with the modern understanding of human rights on some important points. Human rights can be neither under the control of the state nor of society itself, and forms a constitutive part of the individual person. Therefore, the concept of human rights cannot be invalidated by its vulnerability to systemic manipulation (Huber \& Tödt, 1977:163). Here, the connection with the Reformation's radical rediscovery of the inalienable dignity of all persons is clear. However, it diverges from human rights as human dignity was shown to be grounded in God's grace and therefore differs significantly from a stoic-idealistic interpretation of dignity, which understands freedom as the human ability to be at one's own disposal.

According to Huber, human existence is not based on a naive 'free freedom' (freie Freiheit), but always has the character of 'liberated freedom' (befreite Freiheit), as God renews the gift of freedom by liberating the individual person from the power of sin (Huber \& Tödt, 1977:163) and in this sense calls people to one another (cf. again Huber, 1985:118; 1990b:60). Christ's incarnation, death and resurrection enable the renewal of freedom, and God's liberation therefore binds the individual person to Christ. The way in which Christ brought about liberation shapes the freedom to which the person is liberated (cf. also Huber \& Tödt, 1977:164). The liberated freedom brought about by Christ does not initiate a closed relationship between God and the individual person, but opens up the individual to the fundamental relationality of human existence.

\section{To be Human is to be Answerable}

To be human not only means to be liberated, but also means to be answerable. Huber includes responsibility in his understanding of freedom, because he regards being answerable (or accountable) to a number of contexts as part of the human condition. In particular, Dietrich Bonhoeffer's work on responsibility expresses this dimension of being human. In his article 'Sozialethik als Verantwortungsethik' (1990a:136-157) Huber gives one of his clearest explanations of his view on Bonhoeffer's ethics and implicitly his contribution to the discussion on human dignity. In order to structure Bonhoeffer's ethics he identifies two basic contexts of responsibility, namely responsibility before (Verantwortung vor) and responsibility for (Verantwortung für).

Huber (1990a:143) identifies the basic form of responsibility in Bonhoeffer's work as responsibility before God. ${ }^{18}$ According to the Protestant understanding of responsibility, God will ultimately hold humanity responsible for its actions. This basic sense focuses not so much on God's judgement, but rather emphasises the fact that responsibility functions in a framework much wider than the individual life. 'Responsibility before' corresponds with what Huber (1990a:144) calls the 'answer structure' of responsibility in Bonhoeffer's ethics. ${ }^{19}$ Responsibility is the complete answer in reaction to the reality given by God through Christ. Therefore, it concerns the whole of reality and is based on God's actions in defining human reality.

18 Huber, interestingly, does not often take this theme up in this form. When he makes use of the Last Judgement it is more often to identify the criterion by means of which earthly justice will be measured rather than considering God as judge. In this regard, see especially Gerechtigkeit und Recht (1996b:161ff) and also Kirche in der Zeitenwende (1999:192).

19 Cf. Bayer (1995) in which he considers the meaning of personhood in the light of God's justification. 
The second context of responsibility is responsibility for others. Here the willingness for substitutionary action (Stellvertretung) comes into play. ${ }^{20}$ Bonhoeffer's Christology forms the background of this context of responsibility in Huber's work: Christ represents humanity before God and advocates on behalf of humanity, which is the basis for the substitutionary action of Christians on behalf of others (Huber, 2006b). ${ }^{21}$ Christ took the initiative in addressing the predicament of humanity and in this way he freed humanity to express its thankfulness in responsible actions. Therefore, reciprocity is not a prerequisite for responsible action. ${ }^{22}$

Huber integrates the themes of responsibility and substitutionary action in a number of ways in his theology. He develops responsibility, and particularly self-limitation, as the expression of freedom in many of his most important descriptions of communicative freedom, such as in Kirche in der Zeitenwende (1999:210-215), Konflikt und Konsens (1990a:193-194; 204-207), Friedensethik (Huber \& Reuter, 1990:243-246), 'Die Verbindlichkeit der Freiheit' (1993b:70-81) and 'Christliche Freiheit in der freiheitlichen Gesellschaft' (1996a:114-115). Although communicative freedom affirms the inalienable dignity of the individual it does not advance the separation of people, but calls people to one another. The concept of communicative freedom therefore gives expression to the fact that human dignity, by definition, is to be realised in a responsible manner. Such an ethic is characterised by the possibility of self-limitation (Huber, 1990a:193-194, 204-207; 1990b:246; 1993b:70-81; 1999:210-215). ${ }^{23}$

Huber's understanding of self-limitation differs significantly from many conventional understandings of self-control, where the primary concern is one's relationship with oneself. Self-limitation in the sense that Huber uses it, is neither one's 'soul' controlling one's 'body' (as Aristotle understood it); nor does it mean the individual's ability to lead an autonomous life (an idea that gained momentum during the Enlightenment). In the Protestant sense, self-limitation concerns not only the individual person, but also the individual's relationship with other people and with God (Huber, 1999:213). Self-limitation can therefore be understood as 'voluntarily holding back for the sake of others' (Huber, 1999:214). ${ }^{24}$

20 For theological background to the concept of Stellvertretung, cf. e.g. Gestrich (2001); Bieler (996); and Gollwitzer (1967).

21 In his lecture "Flugblätter der Freiheit. Verantwortliches Handeln aus christlichen Wurzeln" Huber (2006b) uses Bonhoeffer's participation in the conspiracy to kill Hitler as example of how substitutionary action and taking over the guilt of others can imply one's alienation from the community of faith: "Mit seinem Eintritt in die Konspiration gegen Hitler begab Bonhoeffer sich weit aus dem Binnenbereich des christlichen Glaubens und der kirchlichen Tätigkeiten hinaus. Er trat hinein in das Inkognito der Verschwörung. Er übte sich in allen Künsten der Verstellung."

22 Cf. Bonhoeffer's conviction that an "uncompromising stand" regarding some convictions is sometimes necessary: "There are things for which an uncompromising stand is worthwhile. And it seems to me that peace and social justice, or Christ himself, are such things" (quoted in Huber, 2006g).

23 The article "Die Verbindlichkeit der Freiheit: Über das Verhältnis von Verbindlichkeit und Freiheit in der evangelischen Ethik" is one of the infrequent instances where Huber (1993b:70-81) develops 'self-limitation' (Selbstbegrenzung) as the 'binding character' (Verbindlichkeit) of freedom.

24 Huber applies the logic of self-limitation within an ethic of responsibility notably to the responsibility of scientists. In the light of the profound influence research in the natural sciences has on technological progress and consequently on society itself, Huber most emphatically argues for an ethic of self-limitation in the context of the natural sciences. His argument is that science needs to be orientated by principles other than 'truth' (Huber, 1990a:205). Although the search for truth should stay an important value for the sciences, humanity's ability to change the natural environment, and indeed to destroy it, may not be left uncalculated anymore (Huber, 1990b:244). Human abilities have changed dramatically: Humanity is now in a position to endanger life itself. This implies that self-limitation cannot be understood as the limitation of freedom but 
Some ethicists have attempted to suggest criteria by means of which self-limitation can be enacted, notably Hans Jonas (cf. e.g. Huber, 1990a:206). He is of the opinion that when the possibilities that technological progress bring about are taken into account, actions should be directed by a heuristic of fear. In accordance with his conviction that ethics should revise its anthropological optimism, he is of the opinion that the human ability to destroy cannot be underestimated. However, Huber prefers to use 'concern' (Betroffenheit) as a criterion (Huber, 1990a:152-154). Huber regards concern as a criterion for selflimitation within an ethics of responsibility, indicating that it has three areas of reference, namely the disempowered members of society, future generations and nature (Huber, 1990a:154). In Huber's view, responsibility is not in contradiction to freedom and the importance of the individual, but rather it serves as its expression.

\section{To be Human is to be in Relationship}

In terms of Huber's work on freedom it can be stated - thirdly - that to be human means to be in relationship. Luther's most famous statement about freedom, and indeed one of the most succinct summaries of the Protestant understanding of freedom, is to be found in his treatise on freedom, Von der Freiheit eines Christenmenschen (1520): 25 "A Christian is a free master over all things and subject to nobody. A Christian is a helpful servant and subject to all." 26 In a sense, this has also become Huber's chosen catchphrase for his understanding of freedom and the human condition as such.

According to this understanding, only the liberated person is truly able to serve freely, as being human means being in relationship. Individualisation does not follow the liberation of the individual conscience, but the 'resurrection of the conscience' (Huber, 1987:62) enables a true openness to others. Luther picked up important impulses from the apostle Paul: Using freedom as 'an opportunity for self-indulgence' contradicts its essence, for liberation implies the freedom to "become slaves to one another [through love]" (Galatians 5:13).

The first of Luther's two statements on freedom was in radical contrast to the conception of freedom common to his time, namely freedom understood as the control over others (Huber, 1985:210). In fact, the Greeks understood the essence of freedom as the power of masters over their servants (Huber, 1985:209). However, in terms of Luther's theology, the first thesis is indicative of the fact that a person is not at the disposal of any centre of power. Importantly, a person is also not a victim of his or her own sin. This thesis confirms human existence as grounded in God's gracious bestowal of dignity and in this radical sense it can be said that humanity is master over all things (Huber, 1999:170). Nothing can ensure or endanger the righteousness of humanity before God, which is why persons are fundamentally free (Huber, 1985:210).

indeed as ensuring that freedom stays possible (Huber, 1999:216). Therefore self-limitation requires consciously distinguishing between what humanity is able to do and what humanity should be allowed to do (Huber, 1990b:245).

25 Huber notably and prominently makes use of Luther's double thesis in Kirche in der Zeitenwende (1999), "Christliche Freiheit in der freiheitlichen Gesellschaft" (1996a) and in important lectures such as "Evangelisch im 21. Jahrhundert" ( 2007b). He also cites Luther's double thesis in many other lectures and speeches. Although these lectures and speeches span a great range of topics Huber's interpretation of the double thesis nearly always follows the contours that are set out in this section.

26 "Ein Christenmensch ist ein freier Herr über alle Dinge und niemand untertan. Ein Christenmensch ist dienstbarer Knecht aller Dinge und jedermann untertan." 
God's constitution of human dignity forms the basis for its relational character (Huber, 1999:168-170; 1996a:104-106). ${ }^{27}$ Not only are creation, salvation and redemption indications of God's initiative in the constitution of freedom, but they are also relational concepts. Relationships initiated and maintained by God are the core of being human. ${ }^{28}$ Bonhoeffer's assertion that in Christ humans see that God is fundamentally for them (pro nobis) (cf. Huber, 2007c) and this not only gives expression to God's initiation of a relationship, but at the same time gives expression to the fact that the human person is always a 'person in relationship' (Person-in-Beziehung) (Huber, 1996a:106).

Huber holds that human individuality and sociality are not in contradiction to one another, but are both the result of God's bestowal of freedom (Huber, 2000). ${ }^{29}$ To give expression to this intimate connection Huber uses the term Gleichursprünglichkeit (most notably in 1990b:57-65). ${ }^{30}$ This term refers to human individuality and sociality as having the 'same source', namely God's bestowal of freedom. ${ }^{31}$ The double-relationality of human dignity (constituted in God's relationship to humanity and realised in relationships with others) consequently corresponds with the two areas of reference that Bonhoeffer identified as 'responsibility before' and 'responsibility for' (Huber, 1990a:143). As has been shown, responsibility before God prevents the ethic that flows from Christian freedom from being totalised (Huber, 1999:183) or individualised (Huber, 1985:115). Taking responsibility for others means respecting the dignity and freedom of conscience of others (Huber, 1990a:247), and includes the willingness for substitutionary action (e.g. Huber, 2007c). ${ }^{32}$

According to this understanding, human dignity is not a 'substance' in need of protection against the dignity of others, but can only be realised relationally (cf. e.g. Huber, 2001a, 2007a). Like freedom it is 'movement', because it moves the person from the desire to control to the ability to serve, which can also be taken as a description of the relational character of human dignity (Huber, 1985:211).

Huber therefore takes up the significance of Bonhoeffer's suggestion that the traditional interpretation of God's actions being 'for me' (pro me) be changed to 'for us' (pro nobis), for God's justification initiates relationships structured not according to the logic of selfpreservation, but according to the logic of self-giving trust in God's liberation (cf. Huber, 2005a, 2006b, 2006f). ${ }^{33}$ By constituting freedom 'for us' God also reveals its true nature,

27 Concerning the relational character of human dignity, cf. also Russel Botman (2003:382) in "A cry for life in a global economic era": "The free individual lives competitively in a market that has become a law unto itself. The fundamentals of the market replace the fundamentals of the community. The anti-community aspect of globalisation ... must be confronted with a revisioning of ecclesiology in terms of the oikos narratives in the Bible. The oikos concept reveals God's intention for building or forming sustainable relationships of people in 'households', of created reality in 'ecosystems', and of churches in the 'ecumene'."

28 Cf. Schwöbel (2002) and in particular the section "Menschsein als Sein-in-Beziehung. Zwölf Thesen für eine christliche Antropologie" (2002:193-226); and Rudman (1997).

29 Cf. e.g. the importance of the responsible realisation of individuality in his speech "Die Rolle der Kirchen als intermediärer Institutionen in der Gesellschaft" (2000): "Die Verwirklichung der eigenen Ziele, des eigenen Lebensplans, der eigenen Interessen soll - und kann - so erfolgen, dass darin die Verantwortung nicht nur für das eigene Leben, sondern für das gemeinsame Leben zur Geltung kommt.”

30 A number of philosophical attempts to reconcile individuality and sociality exist. Cf. e.g. Keller (1994).

31 See specifically Huber (1985:117-118; 1987:53-58; 1990c:105-107; 1996a:61-62; 1999, 169-170) and the sections in this chapter concerning Paul and Luther.

32 Huber delivered this significant recent speech entitled "Dietrich Bonhoeffer - ein evangelischer Heiliger?" (2007c) on Bonhoeffer in Rome and again put strong emphasis on the role of Stellvertretung (substitutionary action) in his work.

33 Huber makes this point succinctly in his lectures "Glauben in der Welt - Die Säkularisierung und Zukunft der Kirchen" (2005a), "Flugblätter der Freiheit. Verantwortliches Handeln aus christlichen Wurzeln" (2006b), 
namely that it means 'being there for others' (Huber, 1985:173). Huber's communicative freedom gives expression to the fact that freedom can only be realised by being there for others, which intimately connects its constitution and realisation with one another. ${ }^{34}$ Praising God and serving others cannot be separated from one another, but are united in communicative freedom (Huber, 2007b):

[Freedom] has its highest fulfilment when it leads to praise to the God who became human for us in Christ. A freedom that is grounded in God's incarnation and that has its fulfilment in praise ... is freedom that is given by God and confirmed in one's relationship with oneself and by interceding for others. ${ }^{35}$

\section{Conclusion}

In this article, it was argued that Wolfgang Huber's work on freedom can be used to construct three statements on human dignity, namely that to be human means one is liberated, answerable and in relationship. This construction was based on the premise that this decidedly Protestant perspective can serve as a meaningful contribution to a multireligious and multi-disciplinary dialogue on human dignity.

"Zukunft gestalten - Erwartungen an Religion und Glaube" (2006e) and "Von der Freiheit der Kinder Gottes - Plädoyer für eine selbstbewusste Kirche" (2006f).

34 In other words, one can say that God's love implies loving one's neighbour, as Huber also states unequivocally: "Wer Gott liebt, liebt auch den Nächsten" (Huber, 2008a:250). Love indeed does not stand in contrast to freedom but serves freedom (2008a:267).

35 "[Freiheit] kommt zu ihrer höchsten Erfüllung, wenn sie sich aufschwingt zum Lob Gottes, der in Jesus Christus uns zu Gute menschliche Gestalt annimmt. Eine in Gottes Menschwerdung begründete Freiheit, die im Lob Gottes ihre Erfüllung findet ... ist eine Freiheit, die sich ein Mensch von Gott schenken last, um sie im Verhältnis zu sich selbst wie im Eintreten für seinen Nächsten zu bewähren.” 


\section{BIBLIOGRAPHY}

Bayer, O 1995. Freiheit als Antwort. Tübingen: Mohr Siebeck.

Berlin, I 1958. Two Concepts of Liberty. Oxford: Oxford University Press.

Berlin, I 2006. Political Ideas in the Romantic Age. Their Rise and Influence on Modern Thought. London: Pimlico.

Bieler, M 1996. Befreiung der Freiheit: Zur Theologie der stellvertretenden Sühne Freiburg im Breisgau: Herder.

Bloom, I, Martin, JP \& Proudfoot, WL 1996 (eds.). Religious diversity and human rights. New York: Columbia University Press.

Botman, R 2003. A cry for life in a global economic era. In M Welker \& WM Alston (eds.), Reformed Theology. Identity and Ecumenicity (pp. 375-384). Grand Rapids: Eerdmans.

Gestrich, C 2001. Christentum und Stellvertretung. Tübingen: Mohr Siebeck.

Gollwitzer, H 1967. Von der Stellvertretung Gottes: Christlicher Glaube in der Erfahrung der Verborgenheit Gottes. Munich: Chr. Kaiser Verlag.

Huber, W 1985. Folgen christlicher Freiheit: Ethik und Theorie der Kirche im Horizont der Barmer theologischen Erklärung. $2^{\text {nd }}$ ed. Neukirchen-Vluyn: Neukirchener Verlag.

Huber, W 1987. Protestantismus und Protest. Reinbek b. Hamburg: Rowohlt Taschenbuch Verlag.

Huber, W 1990a. Konflikt und Konsens. Studien zur Ethik der Verantwortung. Munich: Chr Kaiser Verlag.

Huber, W 1990b. Der Protestantismus und die Ambivalenz der Moderne. In J Moltmann (ed.) Religion der Freiheit. Protestantismus in der Moderne (pp. 29-65). Munich: Kaiser.

Huber, W 1993a. Die tägliche Gewalt: gegen den Ausverkauf der Menschenwürde. Freiburg im Breisgau: Herder.

Huber, W 1993b. Die Verbindlichkeit der Freiheit. Über das Verhältnis von Verbindlichkeit und Freiheit in der evangelischen Ethik. In Zeitschrift für evangelische Ethik 37:70-81.

Huber, W 1996a. Christliche Freiheit in der freiheitlichen Gesellschaft. Evangelische Theologie, 56 (2), 99-116.

Huber, W. (1996b). Gerechtigkeit und Recht. Grundlinien christlicher Rechtsethik. Gütersloh: Chr. Kaiser/Gütersloher Verlagshaus.

Huber, W 1999. Kirche in der Zeitenwende: gesellschafticher Wandel und Erneuerung der Kirche. Gütersloh: Verl. Bertelsmann Stiftung.

Huber, W 2000. Die Rolle der Kirchen als intermediärer Institutionen in der Gesellschaft. Symposion 'Die Zukunft des Sozialen' Humboldt-Universität Berlin, 14. September 2000. Retrieved January 15, 2007, from http://www.ekd.de/vortraege/huber/huberv5.html.

Huber, W 2001a. Gerecht aus Glauben - die Gegenwartsbedeutung des christlichen Menschenbilds. Retrieved January 15, 2007, from http://www.ekd.de/vortraege/huber/vortraege_huber_010926.html. 
Huber, W 2001b. Das Ende der Person? Zur Spannung zwischen Ethik und Gentechnologie. Retrieved January 15, 2007, from http://www.ekd.de/vortraege/huber/5830.html.

Huber, W. (2001c). Rechtfertigung und Recht: Über die christlichen Wurzeln der europäischen Rechtskultur. Baden-Baden: Nomos.

Huber, W. (2004a). Unsterblichkeit und Würde. Kant zu Ehren. Retrieved January 15, 2007, from http://www.ekd.de/vortraege/huber/030216_huber_kant.html

Huber, W 2005a. Glauben in der Welt-Die Säkularisierung und Zukunft der Kirchen. Retrieved January 15, 2007, from http://www.ekd.de/vortraege/huber/051022_huber_maulbronn.html

Huber, W 2005b. Theologie und Kirchenleitung - Vortrag zu Ehren von Eberhard Jüngel, Tübingen. Retrieved January 15, 2007, from http://www.ekd.de/vortraege/huber/050204_huber_ehrung_juengel.html

Huber, W 2006a. Nachfolge heute - Vortrag bei der Jahrestagung der Internationalen Bonhoeffer-Gesellschaft, Deutsche Sektion, in Berlin. Retrieved January 15, 2007, from http://www.ekd.de/vortraege/huber/060915_huber_berlin.html

Huber, W 2006b. Flugblätter der Freiheit. Verantwortliches Handeln aus christlichen Wurzeln. Retrieved January 15, 2007, from http://www.ekd.de/vortraege/huber/060123_huber_weisse_rose.html

Huber, W 2006c. Kirche im Aufbruch - Eine Zeitansage zum Kongressthema der Arbeitsgemeinschaft Missionarische Dienste in Leipzig. Retrieved January 15, 2007, from http://www.ekd.de/vortraege/huber/060918_huber_leipzig.html

Huber, W 2006d. Gemeinschaft gestalten - Evangeliches Profil in Europa - Vortrag auf der 6. Vollversammlung der Gemeinschaft Evangelischer Kirchen in Europa. Retrieved January 15, 2007, from http://www.ekd.de/vortraege/huber/060913_huber_geke_budapest.html

Huber, W 2006e. Zukunft gestalten - Erwartungen an Religion und Glaube - Vortrag beim Advents - Empfang der Kirchenleitungen im Freistaat Sachsen in Dresden. Retrieved January 15, 2007, from http://www.ekd.de/vortraege/huber/061211_huber_dresden.html

Huber, W 2006f. Von der Freiheit der Kinder Gottes - Plädoyer für eine selbstbewusste Kirche/Vortrag auf der Missionale / Köln. Retrieved January 15, 2007, from http://www.ekd.de/vortraege/huber/060401_huber_koeln.html

Huber, W 2006g. WCC $9^{\text {th }}$ Assembly - Wolfgang Huber presentation. Retrieved October 30, 2008, from http://www.wcc-assembly.info/en/theme-issues/assemblydocuments/2-plenary-presentations/economic-justice/wolfgang-huberpresentation.html

Huber, W 2007a. Dass der Mensch mehr ist als seine Taten. Das christliche Menschenbild im Licht der Rechtfertigungsbotschaft - Vortrag bei der Bundeskonferenz der Gefängnisseelsorge in Berlin. Retrieved December 6, 2007, from http://www.ekd.de/vortraege/huber/070509_huber_berlin.html

Huber, W 2007b. Evangelisch im 21. Jahrhundert - Hauptvortrag beim Zukunftskongress in Wittenberg. Retrieved July 17, 2007, from http://www.ekd.de/vortraege/huber/070125_huber_hauptvortrag_zukunftskongress.h tml 
Huber, W 2007c. Dietrich Bonhoeffer - ein evangelischer Heiliger? Vortrag im Ateneo Sant'Anselmo, Rom. Retrieved December 6, 2007, from http://www.ekd.de/vortraege/huber/070503_huber_rom.html

Huber, W 2008. Der christliche Glaube. Eine evangelische Orientierung. Gütersloh: Gütersloher Verlagshaus.

Huber, W \& Reuter, H-R 1990. Friedensethik. Stuttgart: Kohlhammer.

Huber, W \& Tödt, HE 1977. Menschenrechte: Perspektiven einer menschlichen Welt. Stuttgart, Berlin: Kreuz Verlag.

Jüngel, E 1999. Das Evangelium von der Rechtfertigung des Gottlosen als Zentrum des christlichen Glaubens. Tübinen: Mohr Siebeck.

Keller, A 1994. Philosophie der Freiheit. Graz: Verlagshaus Styria.

Rudman, S 1997. Concepts of person and Christian ethics. Cambridge: Cambridge University Press.

Schuhmacher, W 2006. Theologische Ethik als Verantwortungsethik. Leben und Werk Heinz Eduard Tödts in ökumenischer Perspektive. Gütersloh: Gütersloher Verlagshaus.

Schwöbel, C 2002. Gott in Beziehung. Tübingen: Mohr Siebeck.

Stevenson, W 1999. Sovereign Grace: The Place and Significance of Christian Freedom in John Calvin's Political Thought. New York, NY: Oxford University Press.

Theunissen, M 1978. Sein und Schein: Die historische Funktion der Hegelschen Logik Frankfurt am Main: Suhrkamp. 